\title{
Metabolism of Pyraclofos in Rats
}

\author{
Shigeki Tashiro, Hisashi Miyagawa, * Norio Sugita \\ and Yoshiyuki OKada \\ Agricultural Research Laboratories, Agro Division, Takeda Chemical Industries, Ltd., \\ Wadai, Tsukuba 300-42, Japan \\ *Pesticide Research Institute, Faculty of Agriculture, Kyoto University, \\ Sakyo-ku, Kyoto 606, Japan
}

(Received August 17, 1992; Accepted January 18, 1993)

\begin{abstract}
After a single or seven consecutive daily oral administration of pyraclofos $((R, S)-[O$ 1-(4-chlorophenyl)pyrazol-4-yl $O$-ethyl $S$-propyl phosphorothioate], Boltage ${ }^{\circledR}$ ) labeled with ${ }^{14} \mathrm{C}$ at the benzene ring to male and female rats at the rate of $5 \mathrm{mg} / \mathrm{kg}$, radioactivity $\left({ }^{14} \mathrm{C}\right)$ excreted into the urine, feces and expired air in 7 days was $87-95 \%, 4-5 \%$ and less than $0.1 \%$, respectively. The major excretion route was urine. ${ }^{14} \mathrm{C}$ in the blood of both sexes reached maximum $4 \mathrm{hr}$ after administration, and the concentration was relatively high in the liver, kidney and lung. ${ }^{14} \mathrm{C}$ in the brain and spinal cord was extremely low, and there was no accumulation of ${ }^{14} \mathrm{C}$ in the specific tissues 7 days after both single and seven consecutive daily administration. Six metabolites were identified in the urine and feces: 1-(4-chlorophenyl)-4hydroxypyrazole (CHP), sulfate conjugation of CHP, 1-(4-chlorophenyl)pyrazol-4-yl $S$-propyl hydrogen phosphorothioate, 1-(4-chlorophenyl)pyrazol-4-yl O-ethyl hydrogen phosphorothioate, $O$-ethyl $S$-propyl hydrogen phosphorothioate and $O$-ethyl phosphoric acid. The amount of the parent compound was in both urine and feces. Major metabolic pathways of pyraclofos were cleavage of P-O-aryl, P-O-alkyl and P-S-alkyl bonds, and conjugation of $\mathrm{CHP}$ with sulfuric acid.
\end{abstract}

\section{INTRODUCTION}

Pyraclofos $((R, S)-[O-1-(4-$ chlorophenyl)pyrazol-4-yl $O$-ethyl $S$-propyl phosphorothioate], Boltage $\left.{ }^{\circledR}\right)$ has been used for agricultural pest control because of its potent insecticidal activities against a wide range of pest insects, especially larvae of Lepidoptera such as Plutella spp., Spodoptera spp., Pieris spp and Heliothis spp. ${ }^{1-3)}$ Pyraclofos is also effective for controlling filarial worm, Onchocerca volvulu, causing onchocerciasis, a major parasitic disease.

Unlike $O, O$-diethyl phosphate analogues, ${ }^{4-6)}$ pyraclofos, an analogue of $O$-ethyl $S$ - $n$-propyl phosphorothioates per se, is not a strong acetylcholinesterase inhibitor in vitro. ${ }^{7)}$ However, Kono et al. ${ }^{1)}$ have established that pyraclofos is activated to a highly toxic substance by sulfur oxidation in the central nervous system of insects. They have also shown that pyraclofos is detoxified by aliesterases in insects. These findings clearly indicate that the activity and toxicity of pyraclofos greatly depend on its metabolism.

This paper deals with the excretion, tissue distribution and tissue residue of radioactivity after oral administration of ${ }^{14} \mathrm{C}$-labeled pyraclofos to rats. Characterization and quantification of metabolites in the excreta are also described.

\section{MATERIALS AND METHODS}

\section{Chemicals}

${ }^{14} \mathrm{C}$-Labeled pyraclofos, $(R, S)-[O-1$-(4-chloro $\left[\mathrm{U}-{ }^{14} \mathrm{C}\right]$ phenyl)pyrazol-4-yl $O$-ethyl $S$-propyl phosphorothioate] (Fig. 1), was synthesized by Daiichi Pure Chemicals Co., Ltd. according to 


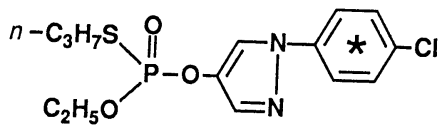

Fig. 1 Chemical structure of pyraclofos. *: ${ }^{14} \mathrm{C}$ labeled position.

the methods prepared by our research laboratories. The specific radioactivity was 185.7 $\mathrm{MBq}(5.02 \mathrm{mCi}) / \mathrm{mmol}$, and the radiochemical purity was more than $99 \%$ by silica gel TLC. The following authentic compounds were prepared in our laboratories: pyraclofos, 1-(4chlorophenyl)-4-hydroxypyrazole (CHP), 1-(4chlorophenyl)pyrazol-4-yl sulfate (CHP-sulfate), $O$-1-(4-chlorophenyl)pyrazol-4-yl $S$-propyl hydrogen phosphorothioate (CHP-SHP), $O$-1-(4-chlorophenyl)pyrazol-4-yl $O$-methyl $S$ propyl phosphorothioate (CHP-SHP-Me), O-1(4-chlorophenyl)pyrazol-4-yl $O$-ethyl hydrogen phosphate (CHP-EHP), O-1-(4-chlorophenyl)pyrazol-4-yl $O$-ethyl $O$-methyl phosphate (CHP-EHP-Me), O-ethyl $S$-propyl hydrogen phosphorothioate (ESP), $O$-ethyl $O$-methyl $S$ propyl phosphorothioate (ESP-Me), ethyl dihydrogen phosphate (EHP) and $O, O$-dimethyl $O$-ethyl phosphate (EHP-Me) (Tables 1 and 2). All other chemicals were reagent grade unless otherwise noted in this paper. Arylsulfatase (E.C.3.1.6.1, type $\mathrm{H}-1$ ) was purchased from Sigma Chemical Co., U.S.A. Scintillators A and $\mathrm{B}$ for radioanalysis were purchased from Wako Pure Chem. Ind., Ltd.

\section{Excretion Balance Study}

Eight week-old Wistar rats were purchased from Clea Japan Inc. and acclimatized for one week. All rats were supplied with a diet (CE2, Nippon CLEA Co., Ltd.) and water ad libitum during the study. ${ }^{14} \mathrm{C}$-Pyraclofos was dissolved in corn oil prior to administration. Three male (body weight, 250-260 g) or three females (200-210 g) received either a single or seven consecutive oral doses at the rate of $5 \mathrm{mg} / \mathrm{kg}$. The rats were individually housed in all-glass metabolism cages (Metabolica CO-2, ${ }^{\circledR}$ Sugiyamagen Iriki Co., Ltd., Japan). The urine and feces were collected separately for 7 days. The expired air of male rats was trapped in an ethanolamine-methyl cellosolve mixture $(25 / 75, \mathrm{v} / \mathrm{v} ; 100 \mathrm{ml})$ by sucking the air $(250 \mathrm{ml} / \mathrm{min})$ for 2 days after a single dose.

\section{Measurement of Radioactivities}

Radioactivity in the urine, solvent extracts and silica gel regions on TLC plate was quantified with a liquid scintillation counter (LSC903, Aloka) with scintillation cocktail A [toluene: $12 l, 1,4$-bis(2-methylstyryl)benzene (bis-MSB) : $12 \mathrm{~g}$, 2,5-diphenyloxazole (DPO) : $15 \mathrm{~g}$, nonion-NS 210: $5.16 l$ (Nihon Yushi)]. A sample oxidizer (ASC-113, Aloka) was used for determination of ${ }^{14} \mathrm{C}$ in the tissues and feces. The ${ }^{14} \mathrm{C}$-carbon dioxide generated by combustion was trapped in OXISORB ${ }^{\mathrm{TM}}-\mathrm{CO}_{2}(\mathrm{Du}$ Pont NEN Research Products), and scintillation cocktail B (toluene: $12 l$, bis-MSB: $12 \mathrm{~g}$, DPO: $15 \mathrm{~g}$ ) was added prior to LSC analysis.

\section{Distribution of ${ }^{14} \mathrm{C}$ to Tissues}

Male and female rats were orally received ${ }^{14} \mathrm{C}$-labeled pyraclofos as described above, and one of the three was sacrificed by bleeding $4 \mathrm{hr}$, 1,7 and/or 14 days after (final) administration. Their tissues were dissected out, and the amounts of ${ }^{14} \mathrm{C}$ distributed to the tissues was determined by radioanalysis.

\section{TLC}

Precoated silica gel $60 \mathrm{~F}_{254}$ chromatoplates $(20 \times 20 \mathrm{~cm}, 0.25 \mathrm{~mm}$ thickness, Merck, F.R.G. $)$ and the following solvent systems were used: A, $n$-hexane-ethyl acetate-methanol (2/2/1, $\mathrm{v} / \mathrm{v})$; $\mathrm{B}$, ethyl acetate-methanol $(5 / 1, \mathrm{v} / \mathrm{v})$; C, $n$-hexane-ethyl acetate $(2 / 1, \mathrm{v} / \mathrm{v}) ; \mathrm{D}, n$ propanol- $\mathrm{H}_{2} \mathrm{O}$-ammonium hydroxide $(10 / 5 / 1$, $\mathrm{v} / \mathrm{v})$. Radioactive spots on TLCs were detected with a TLC chromanyzer (JTC-601, Aloka) and/or by autoradiography (ARG) using an X-ray film (IX Type 150, Fuji Photo Film Co., Ltd.). Nonlabeled authentic compounds were detected under UV light (Topcon FI-31, Tokyo Kogaku Kikai K.K.).

\section{High-Performance Liquid Chromatography (HPLC)}

HPLC analysis was conducted with a Shimadzu LC-3A system equipped with a UV detector (SPD-6A). Analytical conditions for the parent compound and CHP were as follows: column, Nucleosil $\left(10 \mu \mathrm{m}, \mathrm{C}_{18}, 4.0 \mathrm{~mm}\right.$ i.d. 
Table 1 TLC $R f$ values of authentic compounds.

\begin{tabular}{|c|c|c|c|c|c|c|}
\hline \multirow{3}{*}{$\left.\varnothing=-\prod_{=N}^{N} \backslash\right\rangle^{C l}$} & \multirow[b]{3}{*}{ Compound } & \multicolumn{5}{|c|}{$R f$ value } \\
\hline & & \multicolumn{5}{|c|}{ Solvent system } \\
\hline & & $\mathrm{A}$ & $\mathrm{B}$ & $\mathrm{C}$ & $\mathrm{D}$ & $\mathrm{E}$ \\
\hline$(\mathrm{EtO})(\mathrm{PrS}) \mathrm{P}=\mathrm{O}(\mathrm{O} \varnothing)$ & [Pyraclofos] & 0.89 & 0.94 & 0.32 & 0.64 & \\
\hline $\mathrm{H}(\mathrm{O} \varnothing)$ & {$[\mathrm{CHP}]$} & 0.83 & 0.94 & 0.16 & 0.38 & \\
\hline $\mathrm{HO}_{3} \mathrm{~S}(\mathrm{O} \varnothing)$ & [CHP-sulfate] & 0.32 & 0.52 & 0.00 & 0.10 & \\
\hline$(\mathrm{HO})(\mathrm{PrS}) \mathrm{P}=\mathrm{O}(\mathrm{O} \varnothing)$ & {$[\mathrm{CHP}-\mathrm{SHP}]$} & 0.25 & 0.14 & 0.00 & 0.05 & \\
\hline$(\mathrm{EtO})(\mathrm{HO}) \mathrm{P}=\mathrm{O}(\mathrm{O} \varnothing)$ & {$[\mathrm{CHP}-\mathrm{EHP}]$} & 0.13 & 0.06 & 0.00 & 0.05 & \\
\hline$(\mathrm{EtO})(\mathrm{PrS}) \mathrm{P}=\mathrm{O}(\mathrm{OH})$ & {$[\mathrm{ESP}]$} & & & & & 0.65 \\
\hline $\mathrm{EtOP}=\mathrm{O}(\mathrm{OH})_{2}$ & {$[\mathrm{EHP}]$} & & & & & 0.48 \\
\hline
\end{tabular}

Abbreviations: Et, ethyl; Pr, $n$-propyl.

Solvent system: A, hexane-EtOAc-MeOH $(2 / 2 / 1, \mathrm{v} / \mathrm{v}) ; \mathrm{B}$, EtOAc-MeOH $(5 / 1, \mathrm{v} / \mathrm{v})$; C, hexaneEtOAc $(2 / 1, \mathrm{v} / \mathrm{v}) ; \mathrm{D}$, toluene-EtOAc $(4 / 1, \mathrm{v} / \mathrm{v}) ; \mathrm{E}, n-\mathrm{PrOH}-\mathrm{H}_{2} \mathrm{O}-\mathrm{NH}_{4} \mathrm{OH}(10 / 5 / 1, \mathrm{v} / \mathrm{v})$.

Table 2 Characterization of authentic compounds.

\begin{tabular}{|c|c|c|c|c|}
\hline \multirow{2}{*}{$\varnothing=-I_{-N}^{N}$} & \multirow[b]{2}{*}{ Compound } & \multicolumn{3}{|r|}{ GC-MS } \\
\hline & & \multicolumn{2}{|c|}{$\begin{array}{l}R t(\min ), \\
\text { C.T. }\left({ }^{\circ} \mathrm{C}\right)\end{array}$} & $m / z$ \\
\hline$(\mathrm{EtO})(\mathrm{PrS}) \mathrm{P}=\mathrm{O}(\mathrm{O} \varnothing)$ & [Pyraclofos] & $8.7^{\mathrm{b})}$ & $(290)$ & $362,360\left(\mathrm{M}^{+}\right), 318,196,194,139$ \\
\hline $\mathrm{H}(\mathrm{O} \varnothing)^{\mathrm{a})}$ & {$[\mathrm{CHP}]$} & & & $196,194\left(\mathrm{M}^{+}\right), 139$ \\
\hline $\left.\mathrm{H}_{3} \mathrm{C}(\mathrm{O} \varnothing)^{\mathrm{a}}\right)$ & [CHP-Me] & & & $210,208\left(\mathrm{M}^{+}\right), 194$ \\
\hline $\left.\mathrm{HO}_{3} \mathrm{~S}(\mathrm{O} \varnothing)^{\mathrm{d}}\right)$ & [CHP-sulfate] & & & $275,273\left(\mathrm{M}^{+}-\mathrm{H}\right), 239,183$ \\
\hline$\left(\mathrm{CH}_{3} \mathrm{O}\right)(\mathrm{PrS}) \mathrm{P}=\mathrm{O}(\mathrm{O} \varnothing)$ & {$[\mathrm{CHP}-\mathrm{SHP}-\mathrm{Me}]$} & $15.6^{\mathrm{c})}$ & $(260)$ & $348,346\left(\mathrm{M}^{+}\right), 196,194,138$ \\
\hline$(\mathrm{EtO})\left(\mathrm{CH}_{3} \mathrm{O}\right) \mathrm{P}=\mathrm{O}(\mathrm{O} \varnothing)$ & [CHP-EHP-Me] & 8.7 & $(260)$ & $318,316\left(\mathrm{M}^{+}\right), 196,194,138$ \\
\hline$(\mathrm{EtO})(\mathrm{PrS}) \mathrm{P}=\mathrm{O}\left(\mathrm{OCH}_{3}\right)$ & {$[\mathrm{ESP}-\mathrm{Me}]$} & 7.6 & $(150)$ & $198\left(\mathrm{M}^{+}\right), 183,156$ \\
\hline$(\mathrm{EtO}) \mathrm{P}=\mathrm{O}\left(\mathrm{OCH}_{3}\right)_{2}$ & {$[\mathrm{EHP}-\mathrm{Me}]$} & 4.0 & $(150)$ & $153\left(\mathrm{M}^{+}\right), 139,127,110$ \\
\hline
\end{tabular}

Abbreviations: Et, ethyl; Pr, $n$-propyl; $R t$, retention time; C.T., column temp.

a) EI mass by direct insertion. b) CBP-1 (GC column). c) $5 \%$ PEG-20M Gas Chrom Q (GC column).

d) FAB mass (Negative) by direct insertion.

$\times 250 \mathrm{~mm}$, Gasukuro Kogyo), mobile phase, acetonitrile- $\mathrm{H}_{2} \mathrm{O}(6 / 4, \mathrm{v} / \mathrm{v})$, and for $\mathrm{CHP}-$ sulfate, CHP-SHP and CHP-EHP, column, Radial PAK ${ }^{\circledR}\left(10 \mu \mathrm{m}, \mathrm{C}_{18}, 8.0 \mathrm{~mm}\right.$ i.d. $\times 100 \mathrm{~mm}$, Waters), mobile phase, acetonitrile- $-0.02 \mathrm{M}$ $\mathrm{KH}_{2} \mathrm{PO}_{4}(3 / 7, \mathrm{v} / \mathrm{v})$.

\section{Spectroscopy}

The authentic standards employed in this study were confirmed by ${ }^{1} \mathrm{H}$ NMR recorded on a EM-390 Varian spectrometer and mass spectrum. Electron impact and $\mathrm{FAB}$ mass spectra were recorded on Shimadzu (GC-MS, QP-1000) and JEOL (JMS-AX505W) mass spectrometers, respectively. GC was conducted with a Shimadzu GC-7A system under the following conditions: column, CBP-1 $(0.25 \mathrm{~mm}$ i.d. $\times 25$ $\mathrm{m})$ or $5 \%$ PEG-20M Gas Chrom Q (3 mm i.d. $\times 2 \mathrm{~m}, 60 \mathrm{~W}, 80 \mathrm{mesh})$; column temp., $130 \rightarrow$ $160{ }^{\circ} \mathrm{C}\left(5^{\circ} \mathrm{C} / \mathrm{min}\right.$ from $8 \mathrm{~min}$ after injection), detection temp., $200^{\circ} \mathrm{C}$; carrier gas $(\mathrm{He}), 70$ $\mathrm{ml} / \mathrm{min}$ for CBP-1; $30 \mathrm{ml} / \mathrm{min}$ for PEG-20M; detector, flame photometric detector (phosphorus mode) (Table 2).

\section{Identification of Metabolites}

The urine was concentrated under reduced pressure and extracted three times with an equal volume of ethyl acetate. The feces were mixed with a fourfold volume of water and homogenized with a Biomixer (Nihon Seiki). The homogenate was shaken with a fourfold 
volume of methanol and centrifuged. The precipitate was shaken twice with a fourfold volume of methanol, and centrifuged. The supernatants combined were concentrated in vacuo.

Metabolites in the extracts were identified by TLC and/or HPLC cochromatography with authentic standards. Some of them were also confirmed by mass spectrometry. The conjugate isolated was treated with arylsulfatase in $0.2 \mathrm{~N}$ acetate buffer ( $\mathrm{pH} 5.2$ ) at $37^{\circ} \mathrm{C}$ for 1 $\mathrm{hr}$. The reaction mixture was adjusted to $\mathrm{pH}$ 1 with $1 \mathrm{~N} \mathrm{HCl}$, and extracted twice with a threefold volume of ethyl acetate. The extract combined was concentrated and subjected to HPLC analysis.

Polar metabolites treated with diazomethane were identified by GC in comparison with the authentic standards.
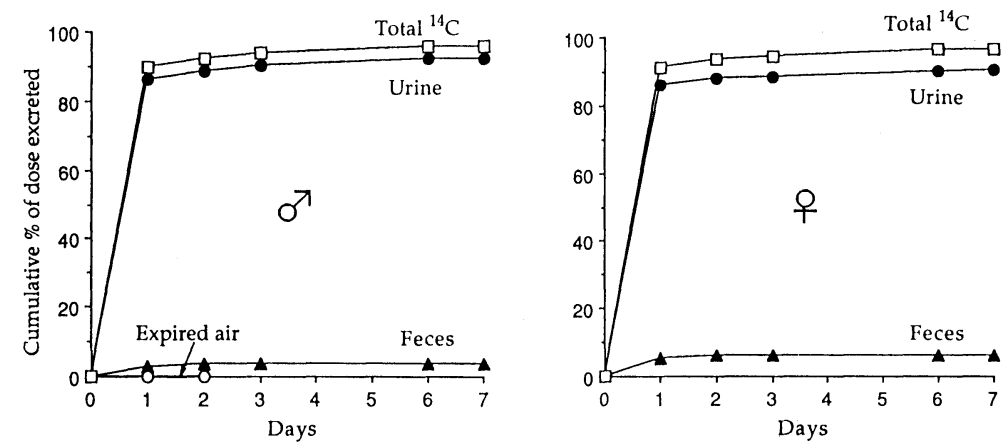

Fig. 2 Cumulative excretion of radioactivity into the urine and feces of male $\left(0^{7}\right)$ and female rats (우) after single oral administration of ${ }^{14} \mathrm{C}$-pyraclofos at the rate of $5 \mathrm{mg} / \mathrm{kg}$.

${ }^{14} \mathrm{C}$ radioactivity in the expired air was less than $0.1 \%$ in male rats 2 days after administration.
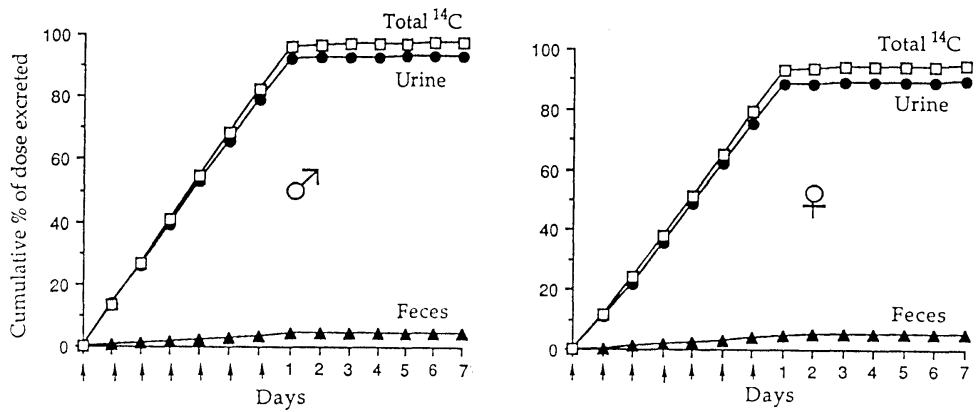

Fig. 3 Cumulative excretion of radioactivity into the urine and feces of male $\left(0^{7}\right)$ and female rats (우) after seven consecutive daily oral administration of ${ }^{14} \mathrm{C}$-pyraclofos at the rate of $5 \mathrm{mg} /$ $\mathrm{kg} /$ day. 
seven consecutive daily administration. The expired ${ }^{14} \mathrm{C}$ in male rats accounted for less than $0.1 \%$ for 2 days after single dose (Fig. 3).

\section{Distribution and Residue Levels of ${ }^{14} \mathrm{C}$ in Tissues}

${ }^{14} \mathrm{C}$ levels in the whole blood of the male and female rats reached maxima $4 \mathrm{hr}$ after dose, and those in the plasma were approximately twice higher than those in the whole blood. Thereafter the concentration of ${ }^{14} \mathrm{C}$ in the whole blood decreased with a half-life of $3.8 \mathrm{hr}$. To examine ${ }^{14} \mathrm{C}$ distribution in the rats, the tissues sampled were radioassayed $4 \mathrm{hr}$ (maximum ${ }^{14} \mathrm{C}$ level in the blood), 2 days (more than $90 \%$ of the dosed ${ }^{14} \mathrm{C}$ excreted) and 7 days after a single or consecutive administration of ${ }^{14} \mathrm{C}$-pyraclofos. The results are shown in Tables 3 and 4.

At $4 \mathrm{hr}$ after single administration, ${ }^{14} \mathrm{C}$ levels were relatively high in the kidney, liver and digestive tissues, while those in the brain and spinal cord were low. Thereafter ${ }^{14} \mathrm{C}$ in the tissues rapidly decreased with time, to very low levels, if any, in all tissues examined except for the liver on day 7 .

After consecutive administration, distribution patterns of ${ }^{14} \mathrm{C}$ in the tissues were similar to the above. Concentrations of ${ }^{14} \mathrm{C}$ in the blood, caecum, intestine, kidney, liver and stomach were about three to seven times higher than those at $4 \mathrm{hr}$ after a single administration. However, ${ }^{14} \mathrm{C}$ disappeared very rapidly thereafter in most tissues, and the residue levels in the tissues on days 7 and 14 were as low as after a single dose.

In both single- and consecutive-administration studies, no substantial sex-related difference was observed.

\section{Quantification of Metabolites in Excreta Metabolites in the urine and feces collected}

Table 3 Distribution of radioactivity in tissues of male and female rats after a single oral administration of pyraclofos ( $5 \mathrm{mg} / \mathrm{kg}$ ).

\begin{tabular}{|c|c|c|c|c|c|c|}
\hline \multirow{3}{*}{ Tissue } & \multicolumn{6}{|c|}{$\mu g$ pyraclofos equivalent/g wet tissue ${ }^{a}$ ) } \\
\hline & \multicolumn{3}{|c|}{ Male } & \multicolumn{3}{|c|}{ Female } \\
\hline & $4 \mathrm{hr}$ & 1 day & 7 days & $4 \mathrm{hr}$ & 1 day & 7 days \\
\hline Adrenal & 0.55 & 0.05 & 0.01 & 0.79 & 0.06 & 0.03 \\
\hline Blood & 2.38 & 0.17 & 0.01 & 3.18 & 0.05 & 0.04 \\
\hline Brain & 006 & 0.01 & 0.00 & 0.07 & 0.01 & 0.01 \\
\hline Caecum & 0.57 & 0.17 & 0.00 & 2.45 & 0.27 & 0.01 \\
\hline Fat & 0.20 & 0.03 & 0.00 & 0.44 & 0.02 & 0.01 \\
\hline Hair & 0.15 & 0.08 & 0.14 & 0.15 & 0.08 & 0.14 \\
\hline Heart & 0.63 & 0.04 & 0.00 & 0.83 & 0.03 & 0.01 \\
\hline Intestine & 3.26 & 0.11 & 0.00 & 2.63 & 0.11 & 0.01 \\
\hline Kidney & 2.90 & 0.19 & 0.01 & 4.73 & 0.51 & 0.05 \\
\hline Liver & 1.95 & 097 & 0.40 & 2.38 & 1.95 & 0.48 \\
\hline Lung & 1.68 & 0.09 & 0.01 & 1.52 & 0.04 & 0.01 \\
\hline Muscle & 0.14 & 0.01 & 0.00 & 0.19 & 0.01 & 0.01 \\
\hline Ovary & & & & 1.01 & 0.02 & 0.01 \\
\hline Pancreas & 0.42 & 0.03 & 0.00 & 0.49 & 0.02 & 0.01 \\
\hline Sciatic nerve & 0.43 & 0.10 & 0.02 & 0.70 & 0.07 & 0.05 \\
\hline Skin & 0.41 & 004 & 0.00 & 0.67 & 0.02 & 0.01 \\
\hline Spinal cord & 0.07 & 0.01 & 000 & 0.09 & 0.02 & 0.01 \\
\hline Spleen & 0.03 & 002 & 0.00 & 0.38 & 0.03 & 0.02 \\
\hline Stomach & 1.84 & $\begin{array}{ll}0 & 04\end{array}$ & 000 & 6.60 & 0.05 & 0.01 \\
\hline Testis & 0.26 & 0.04 & 0.00 & & & \\
\hline Thyroid & 0.72 & 0.09 & 0.01 & 0.83 & 0.08 & 0.06 \\
\hline Uterus & & & & 1.58 & 0.04 & 0.01 \\
\hline
\end{tabular}

a) Values are the mean of three rats. 
Table 4 Distribution of radioactivity in tissues of male and female rats after seven consecutive daily oral administration of ${ }^{14} \mathrm{C}$-pyraclofos $(5 \mathrm{mg} / \mathrm{kg} / \mathrm{day})$.

\begin{tabular}{|c|c|c|c|c|c|c|}
\hline \multirow{3}{*}{ Tissue } & \multicolumn{6}{|c|}{$\mu \mathrm{g}$ pyraclofos equivalent/g wet tissue ${ }^{\mathrm{a}}$ ) } \\
\hline & \multicolumn{3}{|c|}{ Male } & \multicolumn{3}{|c|}{ Female } \\
\hline & $4 \mathrm{hr}$ & 7 days & 14 days & $4 \mathrm{hr}$ & 7 days & 14 days \\
\hline Adrenal & 1.35 & 0.02 & 0.00 & 1.02 & 0.10 & 0.01 \\
\hline Blood & 6.08 & 0.04 & 0.03 & 3.15 & 0.13 & 0.07 \\
\hline Brain & 0.13 & 0.00 & 一 & 0.09 & 0.00 & - \\
\hline Caecum & 4.52 & 0.02 & 0.00 & 3.60 & 0.03 & 0.00 \\
\hline Fat & 0.47 & 0.01 & - & 0.29 & 0.01 & - \\
\hline Hair & 0.25 & 0.12 & 0.03 & 0.89 & 0.06 & 0.03 \\
\hline Heart & 1.55 & 0.01 & - & 0.89 & 0.06 & 0.03 \\
\hline Intestine & 7.98 & 001 & - & 3.14 & 0.03 & 0.00 \\
\hline Kidney & 5.37 & 0.04 & 0.02 & 5.39 & 0.19 & 0.07 \\
\hline Liver & 10.40 & 1.09 & 0.49 & 10.08 & 2.81 & 0.73 \\
\hline Lung & 3.64 & 0.02 & 0.00 & 1.59 & 0.04 & 0.01 \\
\hline Muscle & 0.35 & 0.00 & - & 0.19 & 0.01 & - \\
\hline Ovary & & & & 1.04 & 0.03 & 0.00 \\
\hline Pancreas & 0.55 & 0.01 & - & 0.51 & 0.02 & 0.00 \\
\hline Sciatic nerve & 0.94 & 0.05 & 0.02 & 0.71 & 0.17 & 0.01 \\
\hline Skin & 1.13 & 0.01 & - & 0.60 & 0.03 & 0.00 \\
\hline Spinal cord & 0.21 & 0.01 & - & 0.12 & 0.01 & - \\
\hline Spleen & 0.87 & 0.02 & 0.02 & 0.42 & 0.07 & 0.08 \\
\hline Stomach & 14.10 & 0.01 & - & 17.02 & 0.03 & 0.00 \\
\hline Testis & 1.22 & 0.01 & - & & & \\
\hline Thyroid & 1.12 & 0.02 & 000 & 0.76 & 0.03 & 0.00 \\
\hline Uterus & & & & 1.47 & 0.01 & - \\
\hline
\end{tabular}

a) Values are the mean of three rats.

-: Not analyzed.

from the rats receiving ${ }^{14} \mathrm{C}$-pyraclofos were quantified. The amounts of ${ }^{14} \mathrm{C}$-metabolites are summarized in Table 5. They were purified and characterized by cochromatography with the authentic standards on TLC, HPLC and/or GC-MS.

Most of the ${ }^{14} \mathrm{C}$ in the urine was extracted with ethyl acetate. The major urinary metabolites were identified as CHP-sulfate (produced by cleavage of the P-O-aryl bond and sulfation), CHP-SHP and CHP-EHP (by cleavage of the P-O-Et and P-S-Pr, respectively). CHP-sulfate was treated with arylsulfatase in buffer solution. The released CHP was extracted with ethyl acetate and confirmed by HPLC. The CHP was an insignificant component, and the unmetabolized pyraclofos amounted to very little in the urine.

The metabolites in the feces were apparently similar to those in the urine on TLC, although the parent compound and CHP wer major in the feces. Both in the urine and feces, the amount of polar metabolites detected at the origin on TLC was so small that no further characterization was made.

By comparison of the TLC behavior of the urinary metabolites with that of the authentic standards, $O$-ethyl $S$-propyl hydrogen phosphorothioate (ESP) and $O$-ethyl dihydrogen phosphate (EHP), which were nonradioactive metabolites, were detected. Each ESP and EHP isolated was treated with diazomethane and subjected to GC-MS analysis. The results confirmed their identification. Quantitative analysis of both metabolites by GC after methylation showed that the amount of ESP was relatively larger than that of EHP. Another possible phosphate derivative, $S$-propyl dihydrogen phosphate was not detected, however. 
Table 5 Urinary and fecal excretion of ${ }^{14} \mathrm{C}$ after a single oral administration of pyraclofos to male and female rats $(5 \mathrm{mg} / \mathrm{kg})$.

\begin{tabular}{lrrrr}
\hline \multirow{2}{*}{ Metabolite } & \multicolumn{3}{c}{$\%$ of ${ }^{14} \mathrm{C}$ dosed } \\
\cline { 2 - 4 } & $\left.R f^{\text {a }}\right)$ & \multicolumn{2}{c}{ Urine } & Feces \\
\cline { 2 - 4 } \cline { 5 - 5 } & & Male & Female & Male \\
\hline Pyraclofos & 0.89 & 0.3 & 0.3 & 1.1 \\
CHP & 0.83 & 5.7 & 3.5 & 1.0 \\
CHP-sulfate & 0.32 & 47.0 & 70.6 & 0.4 \\
CHP-SHP & 0.25 & 18.9 & 4.4 & 0.1 \\
CHP-EHP & 0.13 & 12.5 & 4.7 & 0.1 \\
Unknown & 0.00 & 0.2 & 0.5 & 0.3 \\
Unextractable ${ }^{14} \mathrm{C}$ & & $<0.1$ & $<0.1$ & 0.7 \\
Total & & 84.6 & 84.0 & 3.7 \\
\hline
\end{tabular}

a) Solvent system A, hexane-EtOAc-MeOH $(2 / 2 / 1, v / v)$.

Most of the metabolites excreted into the urine and feces were identified in this study.

\section{DISCUSSION}

Proposed metabolic pathways of pyraclofos in rats are illustrated in Fig. 4. Three major metabolic pathways are: 1) cleavage of the $\mathrm{P}-\mathrm{O}$-aryl bond to give CHP and ESP, followed by conjugation of $\mathrm{CHP}$ with sulfuric acid, 2) cleavage of the P-S-alkyl bond to give CHPEHP and 3) cleavage of the P-O-alkyl bond to give CHP-SHP. It is likely that major metabolic pathways of pyraclofos are the same in both sexes, and that dealkylation, dearylation and sulfation $^{8-10)}$ probably play important roles in detoxication of pyraclofos in mammals.

CHP-sulfate was a major urinary metabolite, but the amount of CHP excreted into the urine was small in both sexes. This indicates that most of the CHP produced by dearylation of pyraclofos is quickly conjugated to give sulfate in rats. The sulfation of CHP was more predominant in the females than males, as judged from the larger amount of $\mathrm{CHP}$ sulfate in the excreta of the former.

It has been considered that some phosphorothioates may require metabolic or oxidative activation to exhibit insecticidal activity in vivo, although no activated metabolites have been characterized so far. ${ }^{11-13}$ ) Cytochrome P450-catalyzed oxidation of phosphorothioates in insects is expected to form $S$-oxide capable of phosphorylating acetylcholinesterase (AChE). Segall \& Casida $^{14)}$ have proposed that oxidative conversion of phosphorothioates gives phosphinyloxysulfonate through phosphorothioate $S$-oxide. Kono et al. ${ }^{1)}$ have reported that pyraclofos showed weak activity against AChE of Spodoptera larvae in vitro, when compared with the $O, O$-diethyl phosphate analogues, although it exhibited potent insecticidal activity against the larvae in vivo. The phosphinyloxysulfonate prepared by chemical oxidation of pyraclofos had more potent inhibitory activity in vitro against $\mathrm{AChE}$ of all the insect species tested ( $I_{50}$ value: $7.0-1.2$

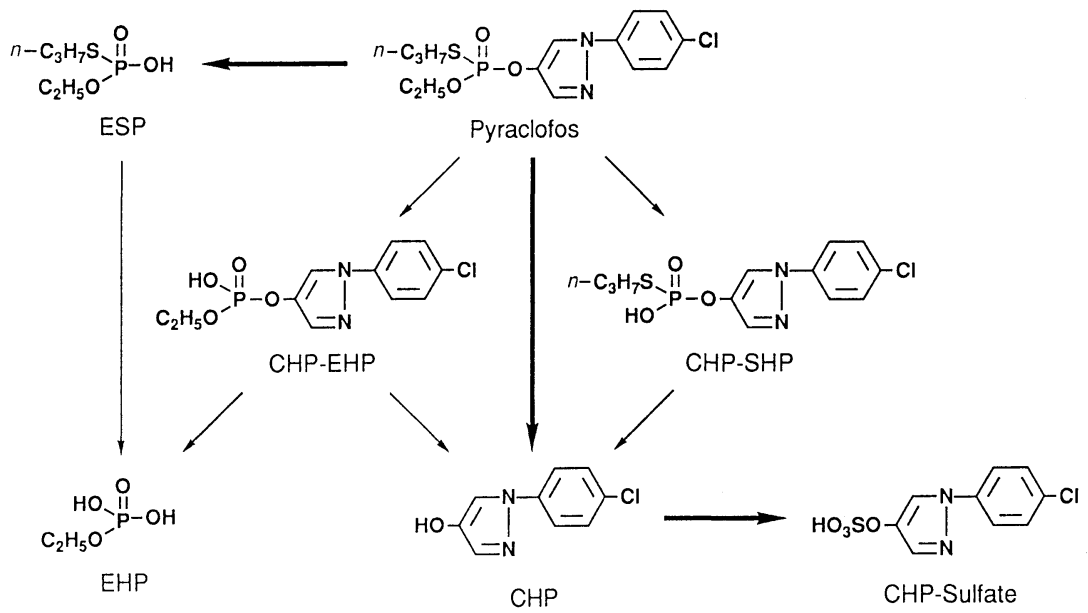

Fig. 4 Proposed metabolic pathways of pyraclofos in rats. 
$\left.\times 10^{-6} \mathrm{M}\right)$ than pyraclofos itself $(4.6-1.0$ $\left.\times 10^{-4} \mathrm{M}\right){ }^{2}{ }^{2}$ These results suggest that oxidative conversion of pyraclofos may take place to give phosphinyloxysulfonate via phosphorothioate $S$-oxide in vivo.

Given these findings, the selective toxicity of pyraclofos can be explained by a difference in metabolic pathways between insects and mammals: Pyraclofos is predominantly subjected to metabolic activation such as sulfur atom oxidation in the nervous system of insects, while it primarily undergoes metabolic detoxication such as cleavage of P-O-aryl bond followed by CHP sulfation in mammals.

\section{REFERENCES}

1) Y. Kono, Y. Sato \& Y. Okada: Pestic. Biochem. Physiol. 20, 225 (1983)

2) Y. Kono \& Y. Manabe: J. Takeda Res. Lab. 42, 330 (1983) (in Japanese)

3) Y. Kono, Y. Sato \& Y. Okada: 5th Int. Congr. Pestic. Chem. (IUPAC), Kyoto, IIa-14, 1982

4) J. Drabek \& V. Flück: "Advances in Pesticide Science," Part 2, International Congress of Pesticide Chemistry, Zurich, p. 130, 1978

5) A. Kudamatsu, A. Iyatomi, A. Hayashi \& R. Kano: Jpn. J. Sanit. Zool. 29, 317 (1978) (in Japanese)

6) A. Kudamatsu, A. Hayashi \& R. Kano: Eisei Dobutsu 28, 285 (1977) (in Japanese)

7) G. J. Hart \& R. D. O'Brien: Pestic. Biochem. Physiol. 6, 85 (1976)

8) G. J. Mulder: "Metabolic Bases of Detoxication," ed. by W. B. Jakoby, J. R. Bend \& J. Caldwell, Academic Press, New York, p. 248, 1982

9) H. Koster, I. Halsema, E. Scholtens, K. S. Pang \& G. J. Mulder: "Sulfate Metabolism and Sulfate Conjugation," ed. by G. J. Mulder,
J. Caldwell, G. M. J. Van Kempen \& R. J. Vonk, Taylor \& Francis, London, p. 125, 1982

10) J. Caldwell: "Xenobiotic Conjugation Chemistry,"” ed. by G. D. Paulson, J. Caldwell, D. H. Hutoson \& J.J. Menn, American Chemical Society, Washington DC, p. 1, 1986

11) M. Eto: "Organophosphorous Pesticide: Organic and Biological Chemistry," CRC Press, Cleaveland, pp. 64, 148, 1974

12) P. Sukdsyretrup \& F. W. Plapp, Jr.: J. Agric. Food Chem. 25, 481 (1977)

13) M. Eto, S. Okabe, Y. Ozoe \& K. Maekawa: Pestic. Biochem. Physiol. 7, 367 (1977)

14) Y. Segall \& J. E. Casida: Tetrahedron Lett. 23, 139 (1982)

\section{要 約}

\section{ピラクロホスのラットにおける代謝}

田代茂喜，宮川 恒，杉田紀夫，岡田嘉之 ピラクロホスのベンゼン環 ${ }^{14} \mathrm{C}$ 一標識体を雌雄ラット に $5 \mathrm{mg} / \mathrm{kg}$ の割合で単回または 7 回連続経口投与する と，いずれも ${ }^{14} \mathrm{C}$ 一放射活性 $\left({ }^{14} \mathrm{C}\right)$ 㯈やかに排泄され， 両投与法による主排泄経路はいずれも尿であった. 単回 投与による尿，傗および呼気中への ${ }^{14} \mathrm{C}$ 一排泄率は投与 後 7 日間に，それぞれ 87〜95\%，4〜5\% および 01 $\%$ 以下であった。投与 4 時間後に血液中の ${ }^{14} \mathrm{C}$ は最高 値を示し, 主要組織中において比較的高い ${ }^{14} \mathrm{C}$ が認めら れたが，脳および㝓髄中では低かった。 なた，連続投与 による最終投与後 7 日目の組織中の ${ }^{14} \mathrm{C}$ もわずかであっ た。雌雄ラットにおける ${ }^{14} \mathrm{C}$ の吸収, 排泄速度, 組織内 分布量，および尿中代謝物の種類および生成率において 顕著な性差はみられず，特定の組織における ${ }^{14} \mathrm{C}$ の蓄積 性も認められなかった。主要代謝物としてはピラクロホ スの $\mathrm{P}-\mathrm{O}-\mathrm{C}$ (アリル基) 結合の開裂により生成したピ ラゾール部の硫酸抱合体，ピラクロホスの脱エチル体お よび脱 S プロピル体であった. 